\title{
PEMETAAN DAERAH RAWAN KONFLIK DI PROVINSI LAMPUNG
}

\section{MAPPING CONFLICT AREAS PRONE IN LAMPUNG PROVINCE}

\author{
Leydi Silvana \\ Badan Penelitian dan Pengembangan Kementerian Dalam Negeri \\ Jlana Kramat Raya No. 132, Senen - Jakarta Pusat \\ e-mail: leydisilvana@yahoo.co.id \\ Diterima: 11 Agustus 2013; direvisi: 31 Agustus 2013; disetujui: 18 September 2013
}

\begin{abstract}
Abstrak
Tujuan penelitian ini adalah untuk mengetahui karakteristik konflik, penyebab dan akar persoalan konflik yang terjadi, mengidentifikasi faktor-faktor apa yang menjadi pemicu konflik, mengetahui langkah-langkah yang telah dilakukan oleh pemerintah untuk mengatasi konflik (kelemahan dan kekuatan) serta merumuskan strategi yang perlu dilakukan untuk mengatasi konflik. Provinsi Lampung merupakan salah satu lokasi penelitian. Dari hasil penelitian kajian ini bersifat deskriptif, dengan metode yang digunakan adalah metode kualitatif. Akar masalah yang menyebabkan Provinsi Lampung sebagai salah satu daerah rawan konflik secara umum disebabkan karena persoalan politik, ekonomi, sosial budaya antar umat beragama, suku etnis, masyarakat dengan pelaku usaha dan distribusi sumber daya alam yang tidak seimbang. Oleh karena itu, hal-hal yang perlu dilakukan pemerintah didalam menangani konflik yang terjadi adalah menciptakan kehidupan yang aman, tentram dan sejahtera, memelihara kondisi damai dan harmonis, meningkatkan tenggang rasa dan toleransi, memelihara keberlangsungan pemerintah, melindungi jiwa, harta benda, sarana umum serta memulihkan fisik sarana \& masyarakat merupakan hal yang penting dilakukan dalam menangani konflik.
\end{abstract}

Kata kunci: konflik, rawan, toleransi.

\begin{abstract}
The purpose of this study was to determine the characteristics of the conflict, the root and the causes of the conflict issues, identify the factors that trigger conflict, knowing the steps taken by the government to resolve the conflict (weaknesses and strengths) and formulate a strategy that needs to be done to resolve the conflict Lampung province is determined as one of the research area. This study is designed to illustrate, elaborate, answer and describe the portrait mapping conflict prone areas in Indonesia. From the research this study is descriptive and the method used is a qualitative method. The root of the problem which led Lampung Province as one of the conflict-prone areas generally caused by political issues, economic, social and cultural inter-religious, ethnic tribes, businesses and communities with the distribution of natural resources that is not balanced. Therefore, the things that need to be done by the government in dealing with the conflict are to create a safe life, peaceful and prosperous, Maintenance of peace and harmony, increase tolerance, maintain continuity of government, to protect life, property, public facilities and restore the physical facilities and the community is an important thing to do in dealing with conflict.

Keywords: conflict, troubled, tolerant.
\end{abstract}

\section{PENDAHULUAN}

Seiring dengan bergulirnya reformasi telah mendorong terjadinya kemajuan-kemajuan di bidang sosial-politik. Reformasi juga memunculkan nilainilai kepemerintahan yang baik (good governance) seperti demokrasi dan transparansi, pemerataan, keadilan dan akuntabilitas yang berorientasi kepada kepentingan rakyat. Dengan demikian perkembangan reformasi di Indonesia telah membawa dampak yang sungguh luar biasa.

Angin segar perubahan tatanan kehidupan politik, ekonomi, sosial, dan budaya yang pada awalnya begitu kencang ditiupkan, ternyata juga memiliki sisi lain yang tidak pernah terbayangkan sebelumnya. Munculnya berbagai tindak kekerasan dan konflik antar elemen masyarakat di berbagai daerah di Indonesia merupakan indikasi yang kuat untuk membuktikan sinyalemen tadi. Semua itu disebabkan adanya ketidakpuasan daerah atas berbagai ketimpangan hubungan, karena tidak diakui dan tidak dihargainya keanekaragaman yang ditabukan seperti : Suku, Agama, Ras dan Antar Golongan (SARA) dalam tatanan sosial. Dalam era Reformasi ini, Indonesia harus mampu mengelola keanekaragaman tersebut dengan bijaksana, agar tercipta hubungan antara unsur-unsur sosial yang berbeda-beda. Penciptaan hubungan sosial yang harmonis dapat tercapai melalui komunikasi yang tulus yang dilandasi oleh pengakuan dan saling penghargaan atas perbedaan-perbedaan yang ada 
demi tercapainya kehidupan sosial yang lebih demokratis.

Akibat dari tidak adanya keterpaduan sosial dan upaya setengah hati untuk membentuk kehendak bersama (common will), maka sebagai suatu bangsa kita terpuruk pada persoalan konflik yang berkepanjangan dan menelan ribuan korban nyawa dan harta benda. Belum lagi apabila kita memikirkan akibat psikologis pada anak-anak yang berada dalam situasi konflik berkepanjangan tersebut.

Masalah konflik bukan hanya masalah emosi sesaat, walaupun bisa terjadi di mana saja serta kapan saja. Sebuah relasi antar manusia apapun bentuknya mempersyaratkan perlunya memahami diri sendiri dan orang-orang lain secara akurat. Dalam kondisi komunikasi antar budaya yang tidak kondusif tersebut, konflik sangat rentan dan terbukti banyak terjadi.

Masyarakat pada saat ini menjadi semakin terbiasa melakukan dan menghadapi berbagai peristiwa konflik dalam kehidupan sehari-harinya, baik yang terjadi dalam lingkup nasional maupun lingkup kedaerahan. Hal ini akhirnya tidak terhindarkan telah mewarnai pola perilaku sosial dalam hubungan interaksi antar warga masyarakat, antar lembaga kemasyarakatan, bahkan antar pemerintah daerah. Perilaku konflik sosial tersebut, dalam sejumlah kasus berlangsung secara tidak terkendali dan mengabaikan norma-norma hukum yang berlaku. Bahkan adakalanya menjurus pada penciptaan situasi kerusuhan yang anarkis dan melebar pada persoalan lain yang tidak berkaitan langsung dengan sumber timbulnya persoalan.

Merebaknya perilaku konflik dan terjadinya perubahan sosial yang berlangsung secara cepat dan cenderung semakin tidak terkendali. Hal ini dapat menyebabkan krisis yang pada gilirannya berdampak pada tersendatnya keberlangsungan pembangunan, berkembangnya aksi main hakim sendiri dan berkembangnya aksi kriminalitas, maraknya aksi berdemonstrasi, semakin menggejalanya euphoria semangat kedaerahan dan ego sektoral yang dimaknai secara sempit, serta terjadinya konflik vertikal dan horizontal di sejumlah daerah, bahkan konflik antar pemerintah daerah yang pada masa lalu sangat jarang terjadi, saat ini dianggap suatu hal yang biasa.

Dari sejumlah kasus konflik yang pernah terjadi tersebut, tidak sedikit yang berdampak pada jatuhnya korban jiwa dan luka-luka serta kerugian material dan immaterial yang begitu besar. Menyikapi terjadinya sejumlah kasus konflik dengan berbagai motif dan bentuk perilaku tersebut, baik dalam lingkup nasional, lingkup daerah, antar warga masyarakat, maka Pemerintah bersama-sama dengan aparat keamanan telah berupaya menanganinya. Dengan berbagai macam cara, sejumlah kasus konflik maupun dampak sosialnya telah berhasil diselesaikan atau sedang dalam proses penyelesaian. Persoalan mengenai munculnya dan yang berkaitan dengan penanganan kasus konflik tersebut, kadangkala menjadi semakin kompleks ketika menjadi meluas ke persoalan atau ke daerah lain atau dipolitisir oleh pihak-pihak tertentu.

Tidak mudahnya proses penyelesaian kasus konflik tersebut, selain merupakan konsekuensi dari kurangnya realisasi dukungan dana dari Pemerintah serta perangkat hukum yang memadai. Hal ini juga disebabkan belum adanya kesamaan pemahaman dan keterpaduan langkah yang terkoordinasi di antara para penyelenggara negara, aparatur pemerintah, aparatur keamanan, dan antar daerah maupun belum kuatnya ketahanan sosial dan dukungan keterlibatan masyarakat dalam menyikapi kasus-kasus konflik tersebut.

Oleh karena itu, guna memberikan kemudahan dan mempercepat upaya penanganan berbagai kasus konflik yang terjadi di sejumlah daerah secara terpadu dan terkoordinasi, maka diperlukan kajian untuk melakukan pemetaan rawan konflik di beberapa daerah dan mencari solusi kebijakan dalam penanganan konflik yang terjadi di daerah. Kajian ini pada hakekatnya bertujuan untuk mengetahui karakteristik konflik, mengetahui penyebab dan akar persoalan konflik yang terjadi, mengidentifikasi faktor-faktor apa yang menjadi pemicu konflik, mengetahui langkah-langkah yang telah dilakukan oleh pemerintah untuk mengatasi konflik (kelemahan dan kekuatan) dan merumuskan strategi yang perlu dilakukan untuk mengatasi konflik.

\section{METODE PENELITIAN}

Kajian ini dirancang untuk dapat menggambarkan, menguraikan, menjawab dan menjabarkan potret pemetaan daerah rawan konflik di Indonesia. Dengan demikian Kajian ini bersifat deskriptif, dengan metode yang digunakan adalah metode kualitatif. Metode ini dipilih untuk dapat menggambarkan fenomena konflik yang terjadi pada lokus kajian yang telah ditetapkan.

Sesuai dengan tujuan kajian, teknik pengumpulan data dan informasi dilakukan melalui penelitian lapangan (field research) dan yang sebelumnya didahului dengan kajian kepustakaan (library research). Kegiatan lapangan dilakukan dengan menggunakan wawancara mendalam (indepth interview) dengan menyiapkan pedoman wawancara dan tinjauan kepustakaan dilakukan melalui penelahaan literatur, dokumen, laporan dinas dan peraturan perundang-undangan yang terkait.

\section{HASIL DAN PEMBAHASAN}

Provinsi Lampung dibentuk berdasarkan Undang-Undang Nomor 14 Tahun 1964 tentang Pembentukan Daerah Tingkat I Lampung tanggal 18 Maret 1964. Secara geografis Provinsi Lampung terletak pada kedudukan $103^{\circ} 40^{\prime \prime}$ (BT) Bujur Timur sampai 105'50" (BT) Bujur Timur dan $3^{\circ} 45^{\prime \prime}$ (LS) 


\begin{tabular}{|c|c|c|c|c|c|c|c|c|}
\hline \multirow[t]{2}{*}{ No. } & \multirow[t]{2}{*}{ Kab./ Kota } & \multicolumn{6}{|c|}{ Jenis Potensi Konflik } & \multirow[t]{2}{*}{ Jml } \\
\hline & & $\begin{array}{c}\text { Antar Umat } \\
\text { Beragama/ } \\
\text { Suku/Etnis }\end{array}$ & Politik & $\begin{array}{c}\text { Batas } \\
\text { Wilayah }\end{array}$ & Industrial & $\begin{array}{c}\text { Agraria/ } \\
\text { Lahan }\end{array}$ & $\begin{array}{c}\text { Sosial/ } \\
\text { Antar } \\
\text { Kelompok }\end{array}$ & \\
\hline 1. & $\begin{array}{l}\text { Bandar } \\
\text { Lampung }\end{array}$ & 2 & 4 & 2 & - & - & 6 & 14 \\
\hline 2. & Metro & - & - & 2 & - & - & 5 & 7 \\
\hline 3. & $\begin{array}{l}\text { Lampung } \\
\text { Selatan }\end{array}$ & - & - & 1 & - & 9 & 12 & 22 \\
\hline 4. & Pesawaran & - & - & 2 & - & 3 & 1 & 6 \\
\hline 5. & $\begin{array}{l}\text { Tulang } \\
\text { Bawang }\end{array}$ & - & 1 & 2 & 1 & 2 & 1 & 7 \\
\hline 6. & $\begin{array}{l}\text { Tulang } \\
\text { Bawang } \\
\text { Barat }\end{array}$ & - & - & 1 & - & 2 & - & 3 \\
\hline 7. & Mesuji & - & - & 1 & 2 & 3 & - & 6 \\
\hline 8. & $\begin{array}{l}\text { Lampung } \\
\text { Utara }\end{array}$ & - & 1 & 2 & - & 5 & 2 & 10 \\
\hline 9. & Way kanan & - & - & 2 & - & 4 & - & 6 \\
\hline 10. & $\begin{array}{l}\text { Lampung } \\
\text { Timur }\end{array}$ & 1 & 1 & 1 & 1 & 3 & 5 & 12 \\
\hline 11. & $\begin{array}{l}\text { Lampung } \\
\text { Barat }\end{array}$ & - & - & 1 & - & 3 & 1 & 5 \\
\hline 12. & Tanggamus & 3 & 1 & 3 & - & 2 & 1 & 10 \\
\hline 13. & Pringsewu & 5 & - & 1 & - & 1 & 2 & 9 \\
\hline \multirow[t]{2}{*}{14.} & $\begin{array}{l}\text { Lampung } \\
\text { Tengah }\end{array}$ & 1 & - & 2 & - & 2 & 8 & 13 \\
\hline & JUMLAH & 12 & 8 & 23 & 4 & 39 & 44 & 130 \\
\hline
\end{tabular}

Sumber: Badan Kesbang dan Politik Provinsi Lampung

Lintang Selatan sampai 645" (LS) Lintang Selatan. Provinsi Lampung meliputi areal daratan seluas $35.288,35 \mathrm{~km}$ (Lampung dalam angka, BPS 2012) termasuk 132 pulau di sekitarnya dan lautan yang berbatasan dalam jarak 12 mil laut dari garis pantai kearah laut lepas. Luas perairan laut Provinsi Lampung diperkirakan lebih kurang $24.820 \mathrm{~km}$ (atlas sumberdaya pesisir Lampung, 1999). Panjang garis pantai Provinsi Lampung lebih kurang $1.105 \mathrm{~km}$, yang membentuk 4 (empat) wilayah pesisir, yaitu Pantai Barat $(210 \mathrm{~km})$, Teluk Semangka (200 km), Teluk Lampung dan Selat Sunda $(160 \mathrm{~km})$, dan Pantai Timur $(270 \mathrm{~km})$.

Pada tahun 2012, Badan Kesbang dan Politik Daerah Provinsi Lampung melakukan pemetaan daerah rawan konflik di 14 (empat belas) Kabupaten/Kota di Provinsi Lampung. Berdasarkan pemetaan yang telah dilakukan, konflik di Provinsi Lampung, dapat dikelompokkan sebagaimana berikut:

1. Konflik antar agama/suku/etnis berjumlah 12 kasus yang terjadi di beberapa wilayah yaitu: Bandar Lampung (2), Lampung Timur (1), Tanggamus (3), Pringsewu (5), dan Lampung Tengah (1).

2. Konflik Politik berjumlah 4 kasus yang terjadi di beberapa wilayah yaitu: Bandar Lampung (1), Tulang Bawang (1), Lampung Utara (1), dan Tanggamus (1).

3. Konflik Batas Wilayah/Daerah berjumlah 20 kasus yang terjadi di semua wilayah.
4. Konflik Industrial berjumlah 4 kasus seperti di Tulang Bawang (1), Mesuji (2), dan Lampung Timur (1).

5. Konflik Agraria/Lahan berjumlah 39 kasus yang tersebar di beberapa Kabupaten/Kota.

6. Konflik Sosial/Antar Kelompok berjumlah 44 kasus yang tersebar di beberapa Kabupaten/Kota.

Untuk lebih jelasnya pengkategorian rawan konflik tersebut diatas dapat dilihat dalam Tabel 1: Data Potensi Konflik Provinsi Lampung Tahun 2013 dibawah. Sedangkan secara detail peta rawan konflik di masing-masing dari 14 Kabupaten/Kota di wilayah Provinsi Lampung dapat dilihat dalam Tabel Rawan Konflik di masing-masing 14 Kab./Kota dalam tabel 1.

Karakteristik konflik di Provinsi Lampung dapat dilakukan pemetaan daerah rawan konflik di 14 (empat belas) Kabupaten/Kota terdapat 130 kasus konflik dan dapat dikelompokkan kedalam jenis potensi konflik antar lain konflik antar umat agama/suku/etnis 12 kasus, Politik 8 kasus, Batas Wilayah 23 kasus, Industrial 4 kasus, Agraria/Lahan 39 kasus dan Sosial/Antar Kelompok 44 kasus. Dari data tersebut diatas kasus terbanyak adalah konflik sosial/antar kelompok sebanyak 44 kasus, namun kasus tersebut terpicu dari konflik Agraria, jadi domain kasus terbesar di Provinsi Lampung adalah masalah Agraria, dan sampai saat ini kasus masalah agraria masih dalam proses penyelesaiannya, mengingat persepsi pemerintah daerah bahwa 
masalah agraria menjadi domain penyelesaian di pemerintah pusat.

Akar masalah penyebab konflik di Provinsi Lampung secara umum dapat disebabkan karena persoalan: Politik, Ekonomi, Sosial BudayaAntar Umat Beragama, Suku Etnis, Masyarakat dengan Pelaku Usaha dan Distribusi Sumber Daya Alam yang tidak seimbang. Dari penjelasan-penjelasan tersebut, dapat dijelaskan bahwa, terjadinya konflik disebabkan hal-hal sebagai berikut:

a) Adanya perbedaan pendirian atau perasaan antara individu dan individu lain sehingga terjadi konflik di antara mereka.

b) Adanya perbedaan kepribadian diantara anggota kelompok disebabkan perbedaan latar belakang budaya.

c) Adanya perbedaan kepentingan atau tujuan diantara individu atau kelompok.

d) Adanya perubahan-perubahan sosial yang cepat dalam masyarakat yang diikuti oleh adanya perubahan nilai-nilai atau system yang berlaku dalam masyarakat.

Konflik adalah suatu pernyataan hidup, tidak terhindarkan dan sering bersifat kreatif.Jika konflik selalu ada, berarti konflik itu memang sebenarnya dibutuhkan. Manfaat konflik antara lain membuat masyarakat menyadari adanya banyak masalah, mendorong kearah perubahan yang dibutuhkan, memperbaiki solusi, menumbuhkan semangat, mempercepat perkembangan pribadi, menambah kepedulian diri, mendorong kedewasaan psikologis dan menimbulkan kesenangan (Tjosvold, 2000). Penyebab konflik antara lain:

1. Kurangnya sumberdaya: dana, alat, orang

2. Sikap berbeda, ketidaksetujuan, komunikasi buruk, lemahnya teamwork (kepercayaan)

3. Struktur organisasi yang tidak cukup dan kurang jelasnya peran.

4. Sedangkan gejala-gejala konflik antara lain:

5. Ada sesuatu yang tidak beres: merasa gelisah, frustasi, terhina, tersakiti hati, sedih, marah dan tidak setuju.

6. Tidak saling bicara

7. Sengaja merusak/menjatuhkan dan tidak kooperatif;

8. Berkontradiksi, berkata-kata tidak baik;

9. Debat, polemik, kelompok-kelompok;

10. Ancaman dan tindakan merusak. Sumber-sumber konflik sosial dikatagorikan pada tiga katagori yakni:

Pertama, Perebutan sumber daya, alat-alat produksi dan kesempatan ekonomi (Access to Economic Resources and to Means of Production)

Kedua, Perluasan batas-batas kelompok sosial budaya (Social \& Cultural Borderline Expansions)

Ketiga, Benturan kepentingan politik, ideology dan agama (Conflict of Political, Ideology And Religious Interest.)

Tidak mudahnya proses penyelesaian kasus konflik, selain merupakan konsekuensi dari kurangnya realisasi dukungan dana dari Pemerintah serta perangkat hukum yang memadai, hal ini juga disebabkan belum adanya kesamaan pemahaman dan keterpaduan langkah yang terkoordinasi di antara para penyelenggara negara, aparatur pemerintah, aparatur keamanan, dan antar daerah maupun belum kuatnya ketahanan sosial dan dukungan keterlibatan masyarakat dalam menyikapi kasus-kasus konflik tersebut.

Dilihat dari pandangan mengenai pihak yang berkonflik dan sumber awal konflik ada tiga pendekatan, yaitu : pendekatan makro, mikro dan pendekatan konvergensi (Abdel Salam, 2004). Pendekatan makro melihat sumber awal atau akar konflik berasal dari adanya persaingan antar kelompok dalam mengejar kekuasaan dan sumber daya yang ada. Pendekatan ini menganalisis konflik antar kelompok pada tataran kesadaran. Pendekatan mikro atau behavior memandang sumber awal konflik dari adanya persaingan antar individu dalam pemenuhan kebutuhan, dan sesuai dengan watak dasar manusia yang agresif. Sementara pendekatan konvergensi, menjelaskan bahwa sumber konflik merupakan paduan antara unsur-unsur yang berasal dari individu dan kelompok. Sering sekali konflik sebenarnya bersifat pribadi, namun karena setiap individu memiliki identitas kelompok tertentu dan ditambah dengan hal-hal tertentu maka menjadi konflik antar kelompok.

Teori konflik muncul sebagai reaksi munculnya teori struktural versus teori fungsional (Karl Marx) pada tahun 1950 dan 1960 an. Teori konflik banyak merebak diimplementasikan yang menyediakan alternatif terhadap pemecahan masalah sesuai teori struktural versus teori fungsional. Definisi konflik merupakan hubungan antara dua pihak atau lebih (individu atau kelompok) yang memiliki, atau yang merasa memiliki, sasaran-sasaran yang tidak sejalan.

Michael E.Brown, menyebutkan terdapat 4 (empat) faktor di mana suatu daerah menjadi lebih rawan konflik dibandingkan daerah lain, yaitu : (1) faktor struktural, misalnya lemahnya Penguasa (Negara/ Pemerintah); (2) faktor politik, misalnya adanya diskriminasi atau pengutamaan kelompok politik tertentu; (3) faktor ekonomi sosial, misalnya adanya resesi, dampak sosial pembangunan dan modernisasi; dan (4) faktor kultural/ persepsi, misalnya adanya diskriminasi kultural/ pertentangan sejarah (Michael Brown, 2001).

Dalam perspektif ilmu sosial, konflik adalah sesuatu yang alamiah dalam kehidupan suatu masyarakat. Namun konflik menjadi persoalan ketika diekspresikan dengan tindakan kekerasan. Kekerasan dapat dilihat sebagai suatu manifestasi dari konflik yang tidak terlembagakan atau terinstitusionalisasikan. Sebaliknya konflik yang terlembagakan dapat dipecahkan secara damai (Tadjoeddin, 2013.). Menurut Sihbudi dan Nurhasim (2001), konflik merupakan faktor yang turut membangun perkembangan masyarakat. Konflik 
akan bisa membangun solidaritas kelompok dan hubungan antar warga negara maupun antar kelompok. Konflik memang tidak terhindarkan, tapi yang terpenting adalah bagaimana cara untuk menyelesaikan konflik agar ancaman (threat) bisa menjadi kesempatan. (opportunity) dan bahaya timbulnya konflik yang terbuka secara meluas bisa dilokalisasi dengan membangun suatu model pencegahan dan penang-. gulangan secara dini (early warning system model). Deskriptif teoritik ini memberikan argumen tentang pentingnya penetuan paradigma di dalam mengkaji konflik sosial, terlebih bila kajian ini akan dijadikan landasan untuk sebuah kebijakan.

Jika dilihat dari dampaknya jenis konflik dapat dibagi ke dalam konflik yang konstruktif dan destruktif. Hal ini tergantung kepada pendekatan dalam melihat konflik. Ada dua pendekatan dalam melihat konflik, yaitu : pendekatan fungsionalisme struktural dan pendekatan konflik.

Pendekatan pertama menganggap masyarakat sebagai sistem yang terdiri dari berbagai bagian, tiap bagian saling terkait dan berfungsi, sehingga berkembang keseimbangan (Nasikun, 1995; Ritzer, 1985). Pendekatan ini mengabaikan kemungkinan suatu sistem menentang fungsi-fungsi lainnya. Dilihat dari tujuan kepentingannya, konflik dapat dibagi ke dalam konflik (dalam budaya) individualistik dan kolektivistik (Ting Toomey dalam Gudykunst et.al, 1988: 278). Perbedaan keduanya dapat dilihat dari unsur penyebab konflik, hubungan isu dan pelaku, kondisi yang mengitari konflik, dan sikap pelaku. Konflik individualistik melihat penyebab konflik sebagai instrumen bukan ekspresif sehingga sering memisahkan isu dengan pelaku konflik. Sebaliknya konflik kolektivistik melihat penyebab konflik lebih sebagai ekspresif, tidak memisahkan antara isu dengan pelaku yang berkonflik, konflik muncul ketika norma kelompok dari pelaku dilanggar, cenderung tidak konfrontatif dan sikapnya tidak langsung terhadap konflik, artinya anggota kelompok berkeinginan kuat membentuk kelompok yang harmonis dan cenderung menggunakan komunikasi tidak langsung.

Ada kajian yang dilakukan oleh Willson dan Rylend yang dikutip oleh Samsu Aman (2006), mereka membahas strategi mengatasi konflik antara lain:

Elimination yaitu suatu sikap untuk mengundurkan diri dari salah satu pihak yang terlibat dalam konflik; Mengurangi domination untuk memberi kepuasan kepada semua pihak yang terlibat dalam konflik;

Minority Consent artinya kelompok mayoritas yang menang namun kelompok minoritas tidak merasa dikalahkan; Kompromi artinya kedua belah pihak yang terlibat dalam konflik bias mencari jalan tengah; dan

Integrasi artinya pendapat-pendapat yang bertentangan didiskusikan, dipertimbangkan Dan ditelaah kembali sampai kelompok mencapai keputusan yang memuaskan bagi semua pihak.

Salah satu kajian tetapi yang cukup komprehensif adalah yang dirumuskan oleh Mark R. Amstudz yang melihat konflik sebagai suatu "continuum" yaitu di satu titik ekstrim terdapat kondisi dan situasi "tak ada masalah / perbedaan" sementara di titik ekstrim satunya terdapat kondisi dan situasi yang diwarnai "perbedaan/ ketidakcocokan".Diantara kedua titik itu terdapat tahapan - tahapan sebagai berikut :

1. Tenssion atau ketegangan

2. Dissagreement atau ketidaksetujuan / ketidaksepakatan

3. Rivalry atau persaingan

4. Dispute atau pertikaian

5. Hostility atau permusuhan

6. Agretion atau agresi

7. Violence ayau kekerasan

8. Warfare atau peperangan

Atau kalau hal itu dilihat sebagai pentahapan berjalannya suatu konflik, maka ada tahap diskusi dan jika masing - masing mau menang sendiri, maka proses berlanjut ke tahap polarisasi, dan perkembangan selanjutnya jika tidak ada lagi obyektifitas maka konflik memasuki tahap segregasi (saling menjauh, putus komunikasi), dan tahap paling berbahaya jika segregasi tidak bisa ditangani secara baik maka konflik memasuki tahap destruktif.

Langkah-langkah yang dilakukan pemerintah dalam mengatasi konflik antara lain :

\section{1) Pencegahan dan Penanganan Konflik}

Dalam rangka pencegahan dan penaganan konflik, Pemprov Lampung telah melakukan untuk melakukan pencegahan dan penanganan konflik, diantaranya:

a. Pencegahan Konflik. Dapat dilakukan dengan:

(1) Memelihara Kondisi Damai Dalam Masyarakat

- mengembangkan sistem penyelesaian perselisihan secara damai;

- meredam potensi konflik dan membangun sistem peringatan dini.

(2) Meliharaan Kondisi Damai Dalam Masyarakat

- Adanya sikap toleransi dan saling menghormati.

- Hormati perbedaan suku, Bahasa, dan Adat Istiadat.

- Mengakui Harkat dan Martabat.

- Mengakui Persamaan derajat dan hak tanpa membedakan suku, keturunan, agama, kepercayaan, jenis kelamin, kedudukan sosial

dan warna kulit.

- Mengembangkan persatuan dan kebinekaan tunggal ikaan Indonesia.

- Menghargai Pendapat dan kebebasan orang lain.

b. Penanganan Konflik

(1) Menciptakan Kehidupan yang aman, tentram dan sejahtera 
(2) Memelihara kondisi damai dan harmonis

(3) Meningkatkan tenggang rasa dan toleransi

(4) Memelihara keberlangsungan pemerintah

(5) Melindungi jiwa, harta benda, sarana umum

(6) Memulihkan fisik sarana \& masyarakat

\section{2) Kewajiban Pemerintah Dalam Meredam Potensi Konflik}

a. Memperhatikan aspirasi masyarakat

b. Menerapkan prinsip tata kelola pemerintahan yang baik

c. Melakukan program perdamaian

d. Mengintensifkan dialog antar kelompok

e. Penegakan hukum tanpa diskriminasi

f. Membangun karakter bangsa;

g. Melestarikan nilai Pancasila dan Kearifan local

h. Menyelenggarakan musyawarah dengan masyarakat dan membangun kemitraan dengan pelaku usaha.

\section{3) Membangun Sistem Peringatan Dini}

a. Penelitian dan pemetaan wilayah potensi konflik;

b. Penyampaian data dan informasi secara cepat dan akurat;

c. Penyelenggaraan Pendidikan dan Pelatihan;

d. Peningkatan dan pemanfatan modal asing;

e. Penguatan dan pemanfaatan fungsi intelijen sesuai dengan ketentuan.

Strategi yang dilakukan untuk mengatasi konflik antara lain :

1) Mensosialisasikan Instruksi Presiden Nomor 2 Tahun 2013 Tentang Penanganan Gangguan Keamanan Dalam Negeri dan Intruksi Menkopolhukam selaku Ketua Tim Terpadu Tingkat Pusat Nomor 1 Tahun 2013 tentang Pelaksanaan Instruksi Presiden Republik Indonesia Nomor 2 Tahun 2013 tentang Penanganan Gangguan Keamanan Dalam Negeri Tahun 2013 kepada seluruh SKPD di lingkungan Pemerintah Provinsi Lampung dan Pemerintah Kabupaten/Kota pada tanggal 05 dan 07 Maret 2013 di Ruang Rapat Badan Kesbang dan Politik Daerah Provinsi Lampung;

2) Membentuk Tim Terpadu dan Menyusun Rencana Aksi Terpadu tingkat Provinsi Lampung berdasarkan kewenangan konflik tingkat Provinsi, dengan melibatkan Satuan Kerja Perangkat Daerah di Lingkungan Pemerintah Provinsi Lampung;

3) Kepada Pemerintah Kabupaten/Kota untuk segera membentuk Tim Terpadu dan Rencana Aksi Terpadu tingkat Kabupaten Kota serta langkah-langkah terpadu guna meredam dan penyelesaian konflik yang terjadi tingkat Kabupaten/Kota, dengan tetap mengedepankan aspek hukum dan norma-norma serta adat istiadat setempat.

4) Untuk menindaklanjuti Inpres Nomor 2 Tahun 2013 tentang Penanganan Gangguan Keamanan
Dalam Negeri, Pemerintah Pusat telah menyusun Rencana Aksi Terpadu Tingkat Nasional dan Pemerintah Provinsi serta Kabupaten/Kota sedang menyusun Rencana Aksi Terpadu Tingkat Daerah dengan berpedoman pada Rencana Aksi Terpadu Tingkat Nasional.

\section{SIMPULAN}

Dari hasil penelitian yang dilakukan di Provinsi Lampung ditemukan akar masalah penyebab konflik antara lain karena persoalan: politik, ekonomi, sosial budaya antar umat beragama, suku etnis, masyarakat dengan pelaku usaha dan distribusi sumber daya alam yang tidak seimbang. Oleh karena itu disarankan agar pemerintah dapat melakukan pencegahan dan penanganan konflik dengan memelihara kondisi damai dalam masyarakat, mengembangkan sistem penyelesaian perselisihan secara damai, meredam potensi konflik dan membangun sistem peringatan dini, menciptakan kehidupan yang aman, tentram dan sejahtera, memelihara kondisi damai dan harmonis, meningkatkan tenggang rasa dan toleransi, memelihara keberlangsungan pemerintah, melindungi jiwa, harta benda, dan sarana umum, serta memulihkan fisik dan sarana masyarakat.

\section{DAFTAR PUSTAKA}

Bangura, Yusuf, 1995. The Search for Identity: Ethnicity, Religion and Political Violence. UNRISD.

Danim, Sudarwan, 2000. Pengantar Studi Penelitian Kebijakan, Bumi Aksara, Jakarta.

Departemen Pendidikan Nasional.2001. Kamus Besar Bahasa Indonesia

Gudykunst et.al., 1988. Cultural and Interpersonal Communication, Sage Publication

Gurr, Robert, 1971. Why Men Rebel, Princeton : Princeton University Press

Hamilton, Peter, 1990. Talcott Parsons dan Pemikirannya, Terj. Hartono. Yogyakarta: Tiara Wacana

Howard Ross, Marc, 1993. The Culture of Conflict, Yale University Press, New Haven And London.

Miall, Hugh. et.al., 2002. Resolusi Damai Konflik Kontemporer Menyelesaikan, Mencegah, dan Mengubah Konflik Bersumber Politik, Sosial, Agama \& Ras,terj.Jakarta : Raja Grafindo Persada

Mitchell, Chris. 1981. The Structure of International Conflict, Macmillan, London

Moleong, Lexy J, 1995. Metodologi Penelitian Kualitatif, Bandung: Remaja Rosdakarya.

Mulyana, Deddy, 2003. Metodologi Penelitian Kualitatif: Paradigma Baru Ilmu Komunikasi dan Sosial lainnya, PT.Remaja Rosdakarya, Bandung.

Nasikun, 1995. Sistem Sosial Indonesia, Jakarta : Raja Grafindo Persada 
Sihbudi, Reza, dkk, 2000. Memahami Gejolak Daerahdaerah Rawan Konflik di Indonesia, Kerjasama Kantor Menristek dengan LIPI, Jakarta

Simon Fisher, 2001. Mengelola Konflik: Keterampilan Dan Strategi Untuk Bertindak,terj. Jakarta, SMK Grafika Desa Putra

Suryadi, (2002) Shaw, Martin. 2001. Bebas dari Militer. Yogyakarta : Insist Press

Stavenhagen, Rodolfo. 1966. Ethnic Conflicts and the Nation-State, Macmillan.

Tjosvold, Dean. 1992. The Conflict-Positive Organisation : Stimulate Diversity and Create Unity, Addisson Wesley

Usman, Sunyoto, 1996. Pembangunan dan Pemberdayaan Masyarakat, Yogyakarta : Pustaka Pelajar

Zubir, Zaiyardam, 2008. Budaya Konflik dan Jaringan Kekerabatan. Teks Buku Ajar, Hibah dari Dikti, Jakarta 